Invited Editorial

ISSN: 2162-3104 Print/ ISSN: 2166-3750 Online

Volume 7, Number 4, October/November (2017) pp. I-III

(C) Journal of International Students

http://jistudents.org/

\title{
Role of Student Affairs in International Student Transition and Success
}

\author{
Guest Co-Editors: \\ Christina W. Yao and Chrystal A. George Mwangi
}

International student mobility has grown significantly in recent years, with over 4.1 million students in 2013 who studied abroad around the world (Institute of International Education [IIE], 2016). With the changes in student demographics and increased mobility, student affairs professionals are in a unique role to support international student transition and success. Unfortunately, current research and practice in higher education tends to place a high level of responsibility on the international student to successfully transition to a new campus environment or places the responsibility on the international student affairs/student services office to solely work with these students. Given the multi-faceted needs of international students, we argue that it is critical for student affairs professionals across functional areas to be prepared to support this diverse population.

In this special issue, scholars and practitioners from around the world provide insight on how different functional areas and professionals can contribute to the transition, inclusion, and success of international students in postsecondary education. We define student affairs broadly as a profession or university unit(s) that advances the mission of higher education institutions via curricular and/or co-curricular functions, supports student learning and development (e.g., academically, emotionally, socially), and encompasses administration, management, advising, and/or counseling services for students (Manning, Kinzie \& Schuh, 2014; Nuss, 2003).

We start with Burt, Knight, and Robeson, who provide insights on the racializing experiences of foreign-born Black graduate students in Engineering, which is a population often omitted from the international 
student literature situated in the United States. Nguyen and Larson continue the theme of supporting graduate students, as they explore the role of student affairs on the academic adjustment and adaptation for Indonesian graduate students. Lee then takes us to New Zealand in a practitioner narrative that discusses the importance of peer networks for international doctoral students.

Authors also address undergraduate international students' experiences with student affairs. Perez-Encinas, Rodriguez-Pomeda, and Josek highlight the challenges facing short-term mobility students in Europe, with implications for student support services at host institutions. International student support is also emphasized in Montgomery's empirical article that illuminates the importance of supporting Chinese first-year students in their transition to U.S. colleges. Naik, Wawrzynski, and Brown examine the outcomes of cocurricular involvement on international students in South Africa, an understudied population in the literature.

Several authors in this special issue provide insights on the role of student affairs and functional areas on international student experiences. Sengupta shares findings related to student expectations of student affairs at the American University of Kurdistan, a new institution developed in a conflict zone. We then learn from Lee and Metcalf about how institutional expectations of academic advising personnel are limited when considering how the student populations in Canada and the U.S. are becoming more internationalized. In a review of "Developing the Global Student: Higher Education in an Era of Globalization," Nasser discusses the book's premise that campus administrators should focus on better preparing U.S. students to engage with international students and a global world as a means of creating a more positive college environment for international students.

Practitioner voices illuminate practical solutions for addressing international students' needs. Boafo-Arthur, Attah, Boafo-Arthur, and Akoensi share personal narratives on how they navigated their host nations as international students from Ghana, with suggestions for student affairs practice. Onyenekwu stresses the importance of culturally relevant services for Black African college students in the United States, with seven helpful suggestions for student affairs professionals. Briggs and Ammigan share an effective collaborative model for structuring a successful international student support office that was implemented at two large U.S. universities. Mata continues the sharing of effective practices, with his recommendations situated in an Ivy League institution. Finally, Starr-Glass takes us on a conceptual reflection on the potentially negative effects of labeling students "international" and how metaphoric labels may limit students' transition and adjustment to their host campus. 
While much of the institutional support for international students is provided from International Student Affairs/Services offices, this special issue demonstrates that all functional areas in Student Affairs have a responsibility to ensure that international students feel supported and included on their college campus. The articles present a fuller understanding of the diverse experiences of international students and the many ways in which student affairs practitioners can engage in targeted work with this student population. We hope that the selection of work presented here helps to inform future research and practice on university resources, programs, and staffing structures that can foster the success of international students.

We want to acknowledge and thank our graduate students, Victoria K. Malaney, Kaleb L. Briscoe, and Crystal E. Garcia, for assisting us with copy editing and general support for this special issue.

\section{References}

Institute of International Education. (2016). Project Atlas- Current Infographics. Washington, D.C.: Institute of International Education.

Manning, K., Kinzie, J., \& Schuh, J.H. (2014). One size does not fit all: Traditional and innovative models of student affairs practice $\left(2^{\text {nd }}\right.$ ed.). New York, NY: Routledge.

Nuss, E.M. (2003). The development of student affairs. In S.R. Komives \& D.B. Woodard, Jr. (Eds.) Student services: A handbook for the profession $\left(4^{\text {th }}\right.$ ed., pp. 65-88). San Francisco, CA: Jossey-Bass.

CHRISTINA W. YAO, Ph.D., is an Assistant Professor of Educational Administration at the University of Nebraska-Lincoln. She studies student engagement and learning in higher education, operationalized through three connected topical areas: international education, teaching and learning, and graduate education. Email: cyao@unl.edu

CHRYSTAL A. GEORGE MWANGI, Ph.D., is an Assistant Professor of Higher Education at the University of Massachusetts Amherst. Her scholarship centers on 1) structures of opportunity $\pi$ and educational attainment for underrepresented populations along the P-20 education pipeline; 2) impacts of globalization and migration on U.S. higher education and 3) African and African Diaspora populations in higher education. Email: chrystal@educ.umass.edu 